\title{
Identifikasi Bulir Superparamagnetik sebagai Prekursor Longsor di Daerah Bukit Lantiak Kecamatan Padang Selatan Kota Padang
}

\author{
Sundari Fatma Effendi*, Arif Budiman \\ Laboratorium Fisika Bumi, Jurusan Fisika \\ Fakultas Matematika dan Ilmu Pengetahuan Alam Universitas Andalas \\ Kampus Unand LimauManis, Padang, 25163 Indonesia \\ *sundarif28@gmail.com
}

\begin{abstract}
ABSTRAK
Telah dilakukan penelitian mengenai identifikasi bulir super paramagnetik sebagai prekursor longsor di Bukit Lantiak Kecamatan Padang Selatan Kota Padang. Sampel diambil pada empat lintasan, dengan setiap lintasan terdapat sepuluh titik pengambilan sampel. Pengukuran nilai suseptibilitas magnetik menggunakan Bartington Magnetic Suseptibility Meter yang diukur pada dua frekuensi, yaitu low frequency $0,465 \mathrm{kHz}\left(\chi_{\mathrm{LF}}\right)$ dan high frequency $4,65 \mathrm{kHz}\left(\chi_{\mathrm{HF}}\right)$. Hasil pengukuran nilai suseptibilitas volum yang didapat dari sampel merupakan mineral Ferrimagnetik, dan nilai suseptibilitas massa yang didapat sampel mengandung mineral Hematit $\left(\mathrm{Fe}_{2} \mathrm{O}_{3}\right)$. Dari analisis hubungan antara ketinggian dan suseptibilitas magnetik sampel, diduga dua lintasan mengalami erosi. Hal ini dikarenakan nilai suseptibilitas magnetik bertambah dengan berkurangnya dengan ketinggian. Berdasarkan keberadaan bulir superparamagnetik, Lintasan C dan D memiliki butiran lebih banyak dibandingkan sampel lokasi A dan B. Tanah yang memiliki butiran halus lebih mudah menyerap air karena memiliki luas permukaan yang lebih besar. Air yang terserap ke dalam tanah akan terakumulasi di atas bidang gelincir, sehingga dapat menyebabkan timbulnya gerak lateral pada tanah atau longsor. Berdasarkan hal tersebut Lintasan C dan D lebih besar kemungkinan terjadinya bencana longsor dibandingkan dengan Lintasan A dan B.

Kata kunci: Bulir Superparamagnetik, Prekursor, Longsor, Suseptibilitas magnetik, Bukit Lantiak
\end{abstract}

\section{ABSTRACT}

Research on the identification of paramagnetic super grains as a landslide precursor in Bukit Lantiak, South Padang District, Padang City has been conducted. Samples are taken on four paths, with ten sampling points in each path. The magnetic susceptibility is measurred using the Bartington Magnetic Suseptibility Meter on two frequencies, namely low frequency $0.465 \mathrm{kHz}(\chi \mathrm{LF})$ and high frequency $4.65 \mathrm{kHz}(\chi \mathrm{HF})$. The results of the susceptibility volume are obtained from the sample Ferrimagnetic minerals, and the susceptibility mass is obtained from the sample that contains Hematite $\left(\mathrm{Fe}_{2} \mathrm{O}_{3}\right)$ minerals. From the analysis of the relationship between the height and magnetic susceptibility of the sample, it is thought that two paths experienced erosion. This is because the value of magnetic susceptibility increases with reduced height. Based on the presence of superparamagnetic grains, Trajectories $C$ and $D$ have more granules than the sample locations $A$ and $B$. Soils that have fine grains are easier to absorb water because it has a larger surface area. Water that is absorbed into the soil will accumulate above the slip plane, so that it can cause lateral movement in the soil or landslides. Based on this, the $C$ and $D$ trajectory is more likely to be a landslide than the A and B trajectories.

Keywords: Superparamagnetic grain, Precursor, Landslides, Magnetic Susceptibility, Bukit Lantiak

\section{PENDAHULUAN}

Longsor merupakan bencana yang sering terjadi di Indonesia. Pada tahun 2015, tercatat telah terjadi bencana longsor pada 501 lokasi di Indonesia yang menyebabkan kerusakan sebanyak 1729 unit rumah (508 rusak berat, 299 rusak sedang, 636 rusak ringan, 286 terendam longsor) dan 21 unit fasilitas umum, serta menewaskan 157 orang. Mengingat banyaknya korban jiwa akibat bencana ini, maka longsor dianggap sebagai bencana yang paling mematikan (BNPB, 2016).

Dampak akibat longsor dapat diminimalisasi apabila peristiwa longsor dapat diprediksi sedini mungkin dengan menyelidiki prekursor atau tanda awal dari peristiwa longsor tersebut. Beberapa indikator yang dapat dijadikan sebagai prekursor dari longsor antara lain kenaikan kapasitas air dalam tanah, guguran material tanah dan debit curah hujan yang terserap oleh tanah. Air hujan seringkali menjadi pemicu terjadinya longsor. Hujan dapat meningkatkan kadar air dalam tanah dan akan menyebabkan kondisi fisik lereng tidak stabil sehingga memperlemah faktor keamanan lereng (Jamil dan Togubu, 2016; Zakaria, 2009). 
Metode yang paling sering digunakan untuk mengetahui potensi longsor adalah metode geolistrik tahanan jenis (Dona dkk, 2015). Metode ini digunakan untuk menentukan letak bidang gelincir pada daerah yang diduga berpotensi longsor. Selain metode geolistrik tahanan jenis, metode kemagnetan batuan dapat digunakan sebagai metode untuk mengetahui akan terjadinya longsor. Besaran fisika yang dipakai dalam metode ini adalah suseptibilitas magnetik. Aplikasi metode kemagnetan batuan untuk mengetahui indikator longsor pertama kali diperkenalkan oleh Kosaka (2000). Pada metode ini potensi longsor diketahui melalui keberadaan bulir superparamagnetik yang terdapat pada tanah permukaan. Keberadaan bulir tersebut dapat diketahui dari nilai suseptibilitas bergantung frekuensi (frequency dependent susceptibility), $\chi_{\mathrm{FD}}(\%) \cdot \chi_{\mathrm{FD}}(\%)$ merupakan selisih antara suseptibilitas frekuensi rendah $\left(\chi_{L F}\right)$ dengan frekuensi tinggi $\left(\chi_{H F}\right)$. Semakin tinggi nilai $\chi_{\mathrm{FD}}(\%)$ maka semakin banyak keberadaan bulir tanah yang bersifat superparamagnetik pada tanah. Bulir tanah yang bersifat superparamagnetik ini disebut dengan bulir superparamagnetik. Partikel-partikel tanah yang berukuran halus mempunyai sifat superparamagnetik. Semakin banyak kandungan bulir superparamagnetik pada suatu tanah, maka semakin banyak partikel tanah yang berukuran halus atau kecil. Semakin halus ukuran partikel semakin mudah menyerap air.

Penerapan metode kemagnetan batuan dalam penelitian tanah longsor telah dilakukan oleh beberapa peneliti. Pratiwi dkk. (2016) melakukan penelitian di daerah Kecamatan Pangalengan, Provinsi Jawa Barat dengan membandingkan lokasi terdampak longsor dan lokasi yang tidak mengalami longsor. Hasil penelitian menunjukkan bahwa lokasi terdampak longsor memiliki nilai $\chi_{\mathrm{FD}}(\%)$ antara $2,65 \%$ hingga $3,33 \%$, sementara lokasi yang tidak terdampak longsor memiliki nilai $\chi_{\mathrm{FD}}(\%)$ antara $0,97 \%$ hingga $2,58 \%$. Ramdhani dkk. (2016) melakukan penelitian tentang hubungan antara nilai suseptibilitas tanah dengan potensi longsor di daerah Pasir Lembang, Bandung Barat. Hasil penelitian ini menunjukkan bahwa sampel-sampel memiliki nilai $\chi_{\mathrm{FD}}(\%)$ yaitu $2,0-10 \%$.

Kota Padang merupakan salah satu daerah di Sumatera Barat yang sering terjadi longsor. Pada rentang tahun 2013-2016 telah terjadi 25 kali longsor di Kota Padang (BPBD, 2013). Salah satu daerah di Kota Padang yang sering terjadi longsor adalah Bukit Lantiak yang terletak di Kelurahan Seberang Palinggam Kecamatan Padang Selatan. Daerah ini memiliki topografi berlereng dengan kemiringan lereng rata-rata $30^{\circ}-60^{\circ}$ (Bappeda Kota Padang, 2009). Mengingat tingginya potensi longsor di daerah Bukit Lantiak dan belum pernah dilakukan penelitian berhubungan dengan longsor yang menggunakan metode kemagnetan batuan, maka dilakukan penelitian yang berhubungan dengan nilai suseptibilitas magnetik tanah sebagai prekursor longsor di Bukit Lantiak.

\section{METODE}

\subsection{Teknik Pengambilan Sampel}

Pengambilan sampel tanah dilakukan di Bukit Lantiak yang terletak di Kelurahan Seberang Palinggam, Kecamatan Padang Selatan Kota Padang. Sampel diambil dari empat lintasan, dengan setiap lintasan terdapat sepuluh titik pengambilan sampel. masing-masing lintasan memiliki panjang $200 \mathrm{~m}$ dengan jarak spasi $20 \mathrm{~m}$, sehingga diperoleh 40 titik pengambilan sampel pada masing-masing lokasi tersebut. Sampel diambil menggunakan pipa PVC. Pipa tersebut ditancapkan ke dalam tanah sejauh $20 \mathrm{~cm}$. Tanah yang berada di ujung pipa diambil secukupnya, lalu dimasukkan ke dalam plastik ziplock yang telah diberi tanda. Sampel yang telah diambil dikeringkan pada temperatur kamar selama 4 x 24 jam. Pengeringan sampel dilakukan agar uap air yang terkandung pada sampel tanah berkurang. Sampel tanah yang sudah dikeringkan tersebut lalu digerus dan kemudian diayak menggunakan saringan 100 mesh. Sebanyak $11 \mathrm{~g}$ sampel tanah tersebut dimasukkan ke dalam sample holder. Pengukuran suseptibilitas magnetik menggunakan MS2B Bartington Susceptibility Meter dengan dua frekuensi, yaitu $0,465 \mathrm{kHz}$ low frequency (LF) dan 4,65 kHz high frequency (HF). Pengukuran nilai suseptibilitas menggunakan 15 arah pengukuran. Data dari hasil pengukuran dicatat, kemudian diolah menggunakan program Matlab 2015a dan microsoft excel. 


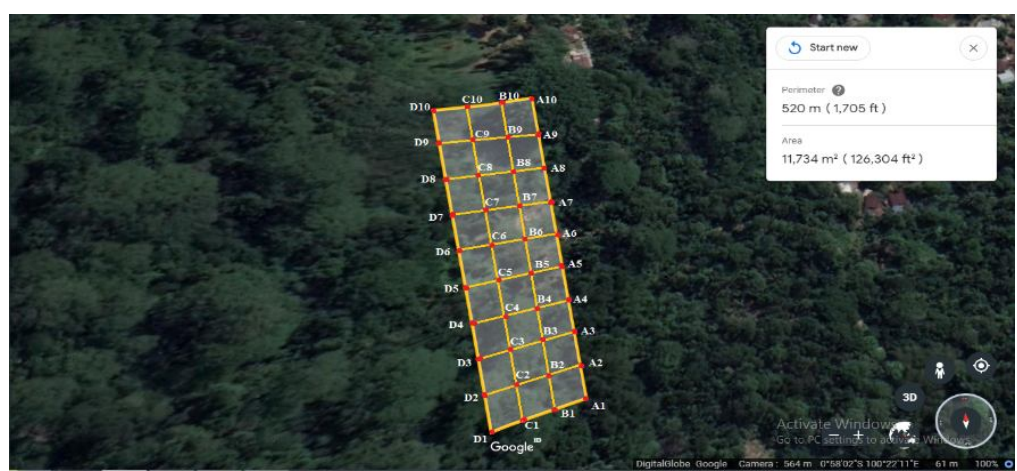

Gambar 1 Lokasi pengambilan sampel.

Pengukuran nilai suseptibilitas magnetik dalam dua frekuensi dimaksudkan untuk memperoleh nilai frequency dependent susceptibility $\chi_{\mathrm{FD}}(\%) \cdot \chi_{\mathrm{FD}}(\%)$ merupakan perubahan suseptibilitas dengan frekuensi rendah $\chi_{\mathrm{LF}}$ dan frekuensi tinggi $\chi_{\mathrm{LF}}$ seperti yang ditunjukkan sesuai Persamaan (1).

$$
\chi_{F D} \%=\frac{\left|\chi_{L F}-\chi_{H F}\right|}{\chi_{L F}} \times 100
$$

Nilai $\chi_{\mathrm{FD}}(\%)$ dapat digunakan untuk mengetahui keberadaan bulir superparamagnetik yang terdapat pada sampel. Interpretasi nilai $\chi_{\mathrm{FD}}(\%)$ terhadap keberadaan bulir superparamagnetik dapat dilihat pada Tabel 1.

Tabel 1 Interpretasi nilai $\chi_{\mathrm{FD}}(\%)$

\begin{tabular}{|c|c|}
\hline Nilai $\chi_{\mathrm{FD}}(\%)$ & Keterangan \\
\hline $0,0-2,0$ & $\begin{array}{l}\text { Tidak ada atau mengandung kurang dari } 10 \% \text { bulir } \\
\text { superparamagnetik }\end{array}$ \\
\hline $2,0-10,0$ & $\begin{array}{c}\text { Mengandung bulir superparamagnetik antara 10\% sampai } \\
\text { dengan } 75 \% \text { yang merupakan campuran antara bulir } \\
\text { superparamagnetik yang berukuran halus dan kasar }\end{array}$ \\
\hline $10,0-14,0$ & $\begin{array}{l}\text { Keseluruhan atau mengandung lebih dari } 75 \% \text { bulir } \\
\text { superparamagnetik }\end{array}$ \\
\hline
\end{tabular}

(Sumber: Dearing, 1999)

Tabel 1 tersebut menunjukkan bahwa semakin tinggi nilai $\chi_{\mathrm{FD}}(\%)$, maka semakin tinggi pula kandungan bulir superparamagnetiknya, namun nilai yang lebih besar dari 14\% adalah sangat jarang dan sering dianggap kesalahan pengukuran (Dearing, 1999), sedangkan hubungan antara nilai $\chi_{\mathrm{FD}}(\%)$ terhadap bulir magnetik dapat dilihat pada Gambar 2.

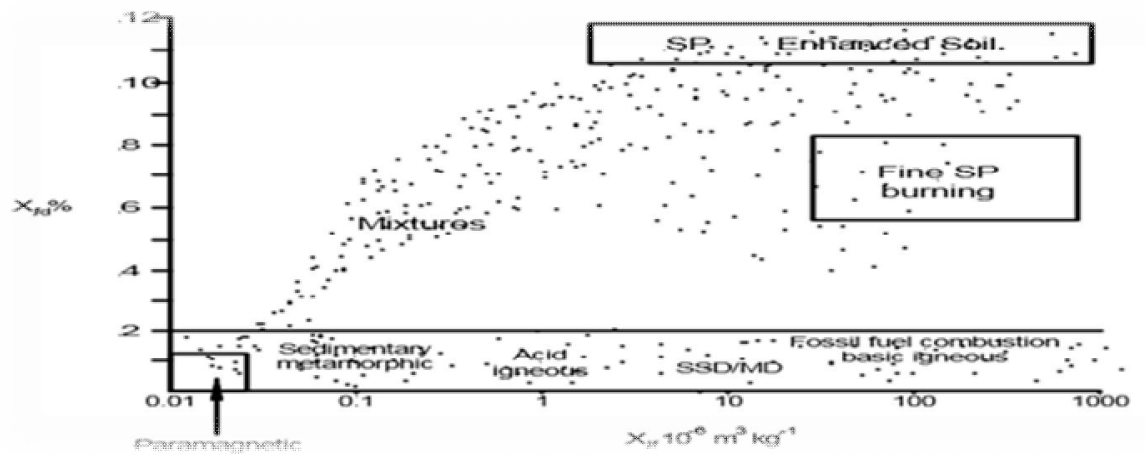

Gambar 2 Scattergram domain magnetik

(Sumber : Dearing, 1999)

Penentuan jenis dan konsentrasi mineral yang terkandung pada sampel dilakukan menggunakan uji X-Ray Fluorescence (XRF). Pengujian ini dilakukan terhadap dua sampel untuk mengetahui hubungan kandungan mineral magnetik terhadap nilai suseptibilitas magnetik sampel. Pemilihan kedua sampel berdasarkan nilai $\chi_{\mathrm{LF}}$ tertinggi pada masing-masing lokasi. 


\section{HASIL DAN DISKUSI}

\subsection{Analisis Nilai Suseptibilitas Magnetik dengan Mineral Magnetik Sampel}

Hasil pengolahan data suseptibilitas magnetik sampel yang berasal dari Lintasan A dapat dilihat pada Tabel 3.

Tabel 2 Hasil pengolahan data suseptibilitas magnetik sampel Lintasan A

\begin{tabular}{cccccccc}
\hline No & $\begin{array}{c}\text { Kode } \\
\text { Sampel }\end{array}$ & $\begin{array}{c}\text { Koordinat } \\
\text { Lintang } \\
(\mathbf{U T M})\end{array}$ & $\begin{array}{c}\text { Koordinat } \\
\text { Bujur } \\
(\mathbf{U T M})\end{array}$ & $\begin{array}{c}\text { Ketinggian } \\
(\mathbf{m d p l})\end{array}$ & $\begin{array}{c}\boldsymbol{\chi}_{\mathbf{L F}} \\
\left(\times \mathbf{1 0}^{-5}\right) \\
(\mathbf{S I})\end{array}$ & $\begin{array}{c}\chi_{\mathbf{H F}} \\
\left(\times \mathbf{1 0}^{-5}\right) \\
(\mathbf{S I})\end{array}$ & $\begin{array}{c}\chi_{\text {FD }} \\
(\mathbf{\%})\end{array}$ \\
\hline 1 & A1 & -0.969722 & 100.369444 & 98 & 3296,0 & 3291,0 & 0,15 \\
2 & A2 & -0.969444 & 100.369472 & 95 & 2860,6 & 2823,5 & 1,30 \\
3 & A3 & -0.969167 & 100.369500 & 90 & 716,60 & 716,00 & 0,08 \\
4 & A4 & -0.968889 & 100.369528 & 88 & 1452,6 & 1422,1 & 2,90 \\
5 & A5 & -0.968611 & 100.369556 & 84 & 1256,3 & 1249,6 & 0,50 \\
6 & A6 & -0.968333 & 100.369583 & 82 & 1362,0 & 1323,3 & 2,80 \\
7 & A7 & -0.968056 & 100.369611 & 79 & 1932,2 & 1907,3 & 1,28 \\
8 & A8 & -0.967778 & 100.369639 & 76 & 548,1 & 525,2 & 4,20 \\
9 & A9 & -0.967500 & 100.369667 & 73 & 1097,3 & 1035,8 & 5,60 \\
10 & A10 & -0.967222 & 100.369694 & 70 & 1095,8 & 1044,6 & 4,67 \\
\hline \multicolumn{7}{c}{ Rata-rata } \\
\hline \multicolumn{7}{c}{}
\end{tabular}

Tabel 3 Hasil pengolahan data suseptibilitas magnetik sampel di Lintasan B

\begin{tabular}{cccccccc}
\hline No & $\begin{array}{c}\text { Kode } \\
\text { Sampel }\end{array}$ & $\begin{array}{c}\text { Koordinat } \\
\text { Lintang } \\
(\mathbf{U T M})\end{array}$ & $\begin{array}{c}\text { Koordinat } \\
\text { Bujur } \\
(\mathbf{U T M})\end{array}$ & $\begin{array}{c}\text { Ketinggian } \\
(\mathbf{m d p l})\end{array}$ & $\begin{array}{c}\boldsymbol{\chi}_{\mathbf{L F}} \\
\left(\times \mathbf{1 0}^{-5}\right) \\
(\mathbf{S I})\end{array}$ & $\begin{array}{c}\chi_{\mathrm{HF}} \\
(\times \mathbf{1 0}) \\
(\mathbf{S I})\end{array}$ & $\begin{array}{c}\chi_{\mathrm{FD}} \\
(\mathbf{\%})\end{array}$ \\
\hline 1 & B1 & -0.969750 & 100.369167 & 104 & 2910,0 & 2880,0 & 1,03 \\
2 & B2 & -0.969472 & 100.369194 & 101 & 2513,1 & 2467,7 & 0,02 \\
3 & B3 & -0.969194 & 100.369222 & 97 & 620,5 & 617,7 & 0,45 \\
4 & B4 & -0.968917 & 100.369250 & 93 & 1278,4 & 1258,2 & 1,58 \\
5 & B5 & -0.968639 & 100.369278 & 91 & 1098,8 & 1085,2 & 1,24 \\
6 & B6 & -0.968361 & 100.369306 & 88 & 1207,5 & 1165,4 & 3,49 \\
7 & B7 & -0.968083 & 100.369333 & 86 & 1671,7 & 1654,1 & 1,05 \\
8 & B8 & -0.967806 & 100.369361 & 83 & 495,2 & 476,5 & 3,63 \\
9 & B9 & -0.967528 & 100.369389 & 80 & 947,3 & 894,7 & 5,55 \\
10 & B10 & -0.967250 & 100.369417 & 78 & 952,3 & 918,9 & 3,51 \\
\hline \multicolumn{7}{c}{ Rata-rata } \\
\hline
\end{tabular}

Tabel 4 Hasil pengolahan data suseptibilitas magnetik sampel di Lintasan C

\begin{tabular}{cccccccc}
\hline No & $\begin{array}{c}\text { Kode } \\
\text { Sampel }\end{array}$ & $\begin{array}{c}\text { Koordinat } \\
\text { Lintang } \\
(\mathbf{U T M})\end{array}$ & $\begin{array}{c}\text { Koordinat } \\
\text { Bujur } \\
(\mathbf{U T M})\end{array}$ & $\begin{array}{c}\text { Ketinggian } \\
(\mathbf{m d p l})\end{array}$ & $\begin{array}{c}\boldsymbol{\chi}_{\mathbf{L F}} \\
\left(\times \mathbf{1 0}^{-5}\right) \\
(\mathbf{S I})\end{array}$ & $\begin{array}{c}\chi_{\mathbf{H F}} \\
\left(\times \mathbf{1 0}^{-5}\right) \\
(\mathbf{S I})\end{array}$ & $\begin{array}{c}\chi_{\mathbf{F D}} \\
(\boldsymbol{\%})\end{array}$ \\
\hline 1 & $\mathrm{C} 1$ & -0.969778 & 100.368889 & 110 & 1171,8 & 1115,6 & 4,80 \\
2 & $\mathrm{C} 2$ & -0.969500 & 100.368917 & 107 & 1026,9 & 1003,2 & 2,31 \\
3 & $\mathrm{C} 3$ & -0.969222 & 100.368944 & 103 & 975,30 & 900,9 & 7,63 \\
4 & $\mathrm{C} 4$ & -0.968944 & 100.368972 & 99 & 1081,5 & 1025,7 & 5,16 \\
5 & $\mathrm{C} 5$ & -0.968667 & 100.369000 & 97 & 1323,0 & 1261,4 & 4,66 \\
6 & $\mathrm{C} 6$ & -0.968389 & 100.369028 & 96 & 1191,2 & 1117,3 & 6,20 \\
7 & $\mathrm{C} 7$ & -0.968111 & 100.369056 & 94 & 672,10 & 636,10 & 5,36 \\
8 & $\mathrm{C} 8$ & -0.967833 & 100.369083 & 92 & 846,90 & 832,50 & 1,70 \\
9 & $\mathrm{C} 9$ & -0.967556 & 100.369111 & 90 & 1762,8 & 1733,8 & 1,64 \\
10 & $\mathrm{C} 10$ & -0.967278 & 100.369139 & 88 & 1725,8 & 1674,8 & 2,89 \\
\hline \multicolumn{7}{c}{ Rata-rata } \\
\hline \multicolumn{7}{c}{}
\end{tabular}


Tabel 5 Hasil pengolahan data suseptibilitas magnetik sampel di Lintasan D

\begin{tabular}{cccccccc}
\hline No & $\begin{array}{c}\text { Kode } \\
\text { Sampe } \\
\text { I }\end{array}$ & $\begin{array}{c}\text { Koordinat } \\
\text { Lintang } \\
(\mathbf{U T M})\end{array}$ & $\begin{array}{c}\text { Koordinat } \\
\text { Bujur } \\
(\mathbf{U T M})\end{array}$ & $\begin{array}{c}\text { Ketinggian } \\
(\mathbf{m d p l})\end{array}$ & $\begin{array}{c}\boldsymbol{\chi}_{\mathbf{L F}} \\
\left(\times \mathbf{1 0}^{-5}\right) \\
(\mathbf{S I})\end{array}$ & $\begin{array}{c}\boldsymbol{\chi}_{\mathbf{H F}} \\
\left(\times \mathbf{1 0}^{-5}\right) \\
(\mathbf{S I})\end{array}$ & $\begin{array}{c}\boldsymbol{\chi}_{\text {FD }} \\
(\mathbf{\%})\end{array}$ \\
\hline 1 & D1 & -0.969806 & 100.368611 & 118 & 1348,4 & 1277,7 & 5,20 \\
2 & D2 & -0.969528 & 100.368639 & 116 & 1158,4 & 1134,7 & 2,00 \\
3 & D3 & -0.969250 & 100.368667 & 113 & 1111,5 & 1044,0 & 6,07 \\
4 & D4 & -0.968972 & 100.368694 & 109 & 1233,3 & 1184,4 & 3,96 \\
5 & D5 & -0.968694 & 100.368722 & 108 & 1530,8 & 1454,9 & 4,96 \\
6 & D6 & -0.968417 & 100.368750 & 107 & 1397,5 & 1312,4 & 6,09 \\
7 & D7 & -0.968139 & 100.368778 & 106 & 774,60 & 726,0 & 6,27 \\
8 & D8 & -0.967861 & 100.368806 & 105 & 974,30 & 963,9 & 1,10 \\
9 & D9 & -0.967583 & 100.368833 & 103 & 2035,0 & 1978,7 & 2,77 \\
10 & D10 & -0.967306 & 100.368861 & 102 & 2045,3 & 1989,5 & 2,70 \\
\hline \multicolumn{7}{c}{ Rata-rata } \\
\hline \multicolumn{7}{c}{}
\end{tabular}

Dari Tabel 2 sampai 5 diketahui seluruh sampel memiliki nilai $\chi_{\mathrm{LF}}$ dengan kisaran antara $495,2 \times 10^{-5}(\mathrm{SI})$ sampai $3291,0 \times 10^{-5}(\mathrm{SI})$, dengan rata-rata $1367,95 \times 10^{-5}(\mathrm{SI})$, dan $\chi_{\mathrm{HF}}$ berkisar antara $476,5 \times 10^{-5}(\mathrm{SI})$ sampai $3296,0 \times 10^{-5}(\mathrm{SI})$, dengan rata-rata $1303,07 \times 10^{-5}(\mathrm{SI})$. Tarling and Hrouda (1993) menyatakan bahwa jika nilai suseptibilitas batuan besar dari $5 \times 10^{-3}$ (SI), suseptibilitasnya dikontrol oleh mineral yang bersifat ferrimagnetik dan jika nilai suseptibilitas batuan antara $5 \times 10^{-4}(\mathrm{SI})$ dan $5 \times 10^{-3}$ (SI), suseptibilitasnya dikontrol oleh mineral yang bersifat ferrimagnetik dan paramagnetik. Dari 40 sampel yang digunakan pada penelitian ini, terdapat 39 sampel nilai suseptibilitasnya dikontrol oleh mineral ferrimagnetik dan satu sampel yang nilai suseptibilitasnya dikontrol oleh mineral ferrimagnetik dan paramagnetik, yaitu B8.

Menurut Mullins (1977) nilai suseptibilitas magnetik tanah bergantung pada kandungan mineral magnetik seperti magnetit, maghemit dan hematit. Jika mengacu pada Tabel 2.1, dapat dilihat bahwa hematit memiliki nilai suseptibilitas antara $10 \times 10^{-8} \mathrm{~m}^{3} \mathrm{~kg}^{-1}$ sampai dengan $760 \times 10^{-8} \mathrm{~m}^{3} \mathrm{~kg}^{-1}$. Dikarenakan nilai suseptibilitas tersebut merupakan nilai suseptibilitas massa, sedangkan pengolahan sampel menggunakan susebtibilitas volum, maka perlu dikonversi terlebih dahulu menjadi suseptibilitas massa. Konversi dilakukan dengan cara membagi nilai suseptibilitas volum dengan massa jenis sampel $\rho$ yaitu $4,33 \mathrm{~g} / \mathrm{cm}^{3}$. Hasil perhitungan diperoleh nilai suseptibilitas massa untuk keseluruhan sampel berkisar dari $114,82 \times 10^{-8} \mathrm{~m}^{3} \mathrm{~kg}^{-1}$ (B8) sampai dengan $763,55 \times 10^{-8} \mathrm{~m}^{3} \mathrm{~kg}^{-1}$ (A1). Oleh karena itu dapat diperkirakan bahwa mineral magnetik yang terkandung pada sampel dari keempat lintasan adalah hematit $\left(\mathrm{Fe}_{2} \mathrm{O}_{3}\right)$.

Nilai rata-rata suseptibilitas berturut-turut untuk $\chi_{\mathrm{LF}}$ dan $\chi_{\mathrm{HF}}$, sampel dari Lintasan A mempunyai nilai tertinggi $\left(1561,7 \times 10^{-5}(\mathrm{SI})\right.$ dan $\left.1533,8 \times 10^{-5}(\mathrm{SI})\right)$, diikuti oleh sampel Lintasan B $\left(1367,5 \times 10^{-5}(\mathrm{SI})\right.$ dan $\left.1341,8 \times 10^{-5}(\mathrm{SI})\right)$, C $\left(1177,7 \times 10^{-5}(\mathrm{SI})\right.$ dan $\left.1030,1 \times 10^{-5}(\mathrm{SI})\right)$ dan D $\left(1360,9 \times 10^{-5}(\mathrm{SI})\right.$ dan $\left.1306,6 \times 10^{-5}(\mathrm{SI})\right)$. Berdasarkan analisis sebelumnya diperkirakan bahwa mineral magnetik yang terkandung pada setiap sampel adalah hematit yang bersifat ferimagnetik. Disamping itu sampel diambil dari lokasi yang berdekatan, sehingga dapat dikatakan sampel memiliki jenis mineral magnetik yang sama. Oleh karena itu perbedaan nilai suseptibilitas dari sampel-sampel tersebut disebabkan oleh perbedaan konsenterasi mineral magnetiknya.

Bukit Lantiak memiliki empat jenis batuan yaitu batuan Clay, batuan Sandstone, batuan Limestone, dan batuan Andesite, tetapi lebih didominasi oleh batuan Andesite berselingan dengan Tufa. Batuan Andesite itu sendiri memiliki tiga belas jenis mineral penyusun utama yaitu kristobalit, prehnit kuarsa, anortit, nephilit, piroksen, ibnenit, hornblende, hematit, muscovit, magnetit, dan olivine (Dona dkk, 2015; Taslimah, 1999). Hal ini terbukti dari hasil pengukuran nilai suseptibilitas magnetik yang di dapat di seluruh sampel mengandung hematit.

\subsection{Hubungan $\chi_{\mathrm{FD}}(\%)$ dengan Bulir Superparamagnetik}

Dari Tabel 2 sampai dengan 5 dapat dilihat perbedaan hasil pengukuran suseptibilitas magnetik menggunakan frekuensi rendah $\left(\chi_{\mathrm{LF}}\right)$ dan frekuensi tinggi $\left(\chi_{\mathrm{HF}}\right)$. Dari hasil perhitungan 
untuk keseluruhan sampel terlihat bahwa nilai $\chi_{\mathrm{LF}}$ lebih besar dari nilai $\chi_{\mathrm{HF}}$. Hal ini dikarenakan sampel sampel tersebut mengandung bulir superparamagnetik. Pada pengukuran $\chi_{\mathrm{HF}}$ tidak memungkinkan bagi bulir superparamagnetik berinteraksi dengan medan magnetik luar yang digunakan. Hal ini disebabkan perubahan medan magnetik luar yang digunakan pada pengukuran $\chi_{\mathrm{HF}}$ lebih cepat dibandingkan waktu relaksasi yang diperlukan untuk bulir superparamagnetik. Akibatnya, pengukuran dalam frekuensi yang lebih tinggi nilai-nilai suseptibilitas yang diperoleh lebih rendah dari pada pengukuran frekuensi yang lebih rendah (Thompson dan Oldfield, 1986 dalam Solomon, dkk, 2017).

Nilai $\chi_{\mathrm{FD}}(\%)$ untuk seluruh sampel berkisar antara 0,02\%-7,63\% dengan rata-rata $3,19 \%$. Sebaran sampel berdasarkan nilai $\chi_{\mathrm{FD}}(\%)$ pada lokasi penelitian dapat dilihat pada Gambar 3 dari gambar terlihat bahwa sampel yang memiliki $\chi_{\mathrm{FD}}(\%)$ besar atau sama dengan $2,00 \%$ lebih banyak dari pada sampel yang memiliki $\chi_{\mathrm{FD}}(\%)$ kurang dari $2,00 \%$. Terdapat 26 sampel dari 40 sampel yang mempunyai $\chi_{\mathrm{FD}}(\%)$ besar atau sama dengan $2,00 \%$ sedangkan sisanya memiliki $\chi_{\mathrm{FD}}(\%)$ kurang dari 2,00\%. Jika mengacu pada Tabel 2 sampai 5 terlihat bahwa 26 sampel tersebut mengandung bulir superparamagnetik antara 10\% sampai dengan 75\% yang merupakan campuran antara bulir superparamagnetik yang berukuran halus dan kasar, sedangkan 14 sampel yang lain mengandung bulir seperparamagnetik kurang dari $10 \%$.

Jika dilakukan perhitungan antara hubungan linier antara $\chi_{\mathrm{FD}}(\%)$ dan persentase kandungan bulir supeparamagnetik terhadap keseluruhan bulir pada sampel untuk $\chi_{\mathrm{FD}}(\%)$ besar atau sama dengan $2,00 \%$, maka diperoleh setiap kenaikan $\chi_{\mathrm{FD}}(\%)$ sebesar $1,00 \%$ maka terdapat kenaikan jumlah kandungan bulir superparamagnetik sebesar 8,125\%. Dari perhitungan tersebut diperoleh jika $\chi_{\mathrm{FD}}(\%)$ adalah $7,00 \%$ maka kandungan bulir superparamgnetiknya sebesar $50,625 \%$. Jadi semua sampel yang memiliki $\chi_{\mathrm{FD}}(\%)$ di atas $2,00 \%$ memiliki kandungan superparamagnetik kurang dari $50 \%$, kecuali sampel $\mathrm{C} 3$ yang memiliki nilai $\chi_{\mathrm{FD}}(\%)$ yaitu $7,63 \%$.

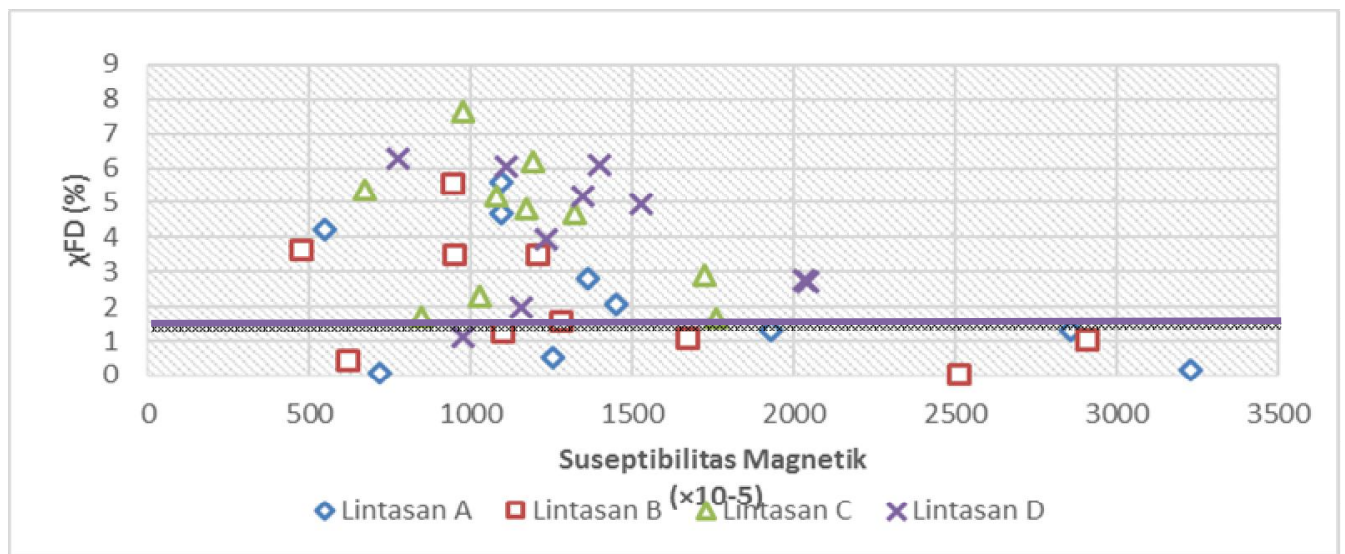

Gambar 3 Grafik hubungan antara nilai suseptibilitas sampel terhadap $\chi_{\mathrm{FD}}(\%)$

\subsection{Analisis Nilai Susebtibilitas Magnetik dengan Erosi dan Longsor}

Hubungan antara ketinggian titik pengambilan sampel pada empat lintasan pada lokasi penelitian dengan nilai $\chi_{\mathrm{LF}}$ dapat dilihat pada peta kontur nilai $\chi_{\mathrm{LF}}$ seperti yang ditunjukkan pada Gambar 4. Untuk Lintasan A dimulai dari A1 sampai dengan A10. Dari gambar terlihat bahwa nilai suseptibilitas magnetik sampel berbanding lurus dengan ketinggian, hal ini juga sama dengan sampel-sampel pada Lintasan B. Sebaliknya untuk Lintasan C dan D terlihat bahwa semakin rendah ketinggian sampel nilai suseptibilitas yang didapatkan semakin tinggi.

Menurut Nazarok dkk, (2014) suseptibilitas magnetik memiliki hubungan statistik yang erat dengan erosi. Pada daerah yang diduga mengalami erosi lokasi yang memiliki tanah dengan nilai suseptibilitas lebih rendah dikatakan telah mengalami erosi. Disamping itu, erosi pada suatu daerah juga dapat dilihat dari hubungan ketinggian tempat pengambilan sampel dengan nilai suseptibilitas sampel. Dearing, dkk (1985) menyatakan bahwa aliran air yang menghanyutkan mineral magnetik dalam tanah sehingga dapat mempengaruhi nilai suseptibilitas tanah tersebut. Aliran air akan menuju ke arah titik yang lebih rendah, sehingga 
pada titik yang lebih rendah akan terjadi penumpukan mineral magnetik yang menyebabkan meningkatkan nilai susebtibilitas magnetik pada titik tersebut. Oleh karena itu dapat tanah pada Lintasan A dan B dikatakan tidak mengalami erosi, sedangkan Lintassan C dan D rawan akan terjadinya erosi. Hal ini sesuai dengan analisis sebelumnya bahwa telah mengalami erosi.

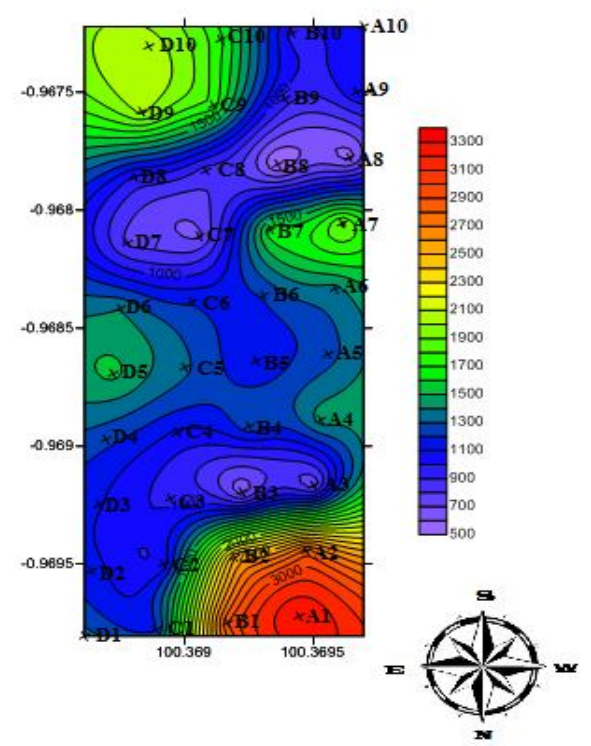

Gambar 4 Peta kontur sebaran $\chi_{\mathrm{LF}}$ pada empat lintasan pengambilan sampel

Untuk menganalisis potensi longsor di lokasi penelitian dilakukan pembuatan peta kontur nilai $\chi_{\mathrm{FD}}(\%)$ seperti pada Gambar 5. Menurut Pratiwi (2016) lokasi terdampak longsor memiliki nilai $\chi_{\mathrm{FD}}(\%)$ antara $2,65 \%$ hingga $3,33 \%$. Jadi dapat dikatakan bahwa lintasan yang memiliki nilai $\chi_{\mathrm{FD}}(\%)$ di atas $2,5 \%$ rawan akan terjadinya longsor. Dari gambar dapat dilihat bahwa Lintasan A dan B memiliki nilai $\chi_{\mathrm{FD}}(\%)$ di bawah 2,5\%, kecuali bagian bawah dari Lintasan A (A6, A8, A9, A10) dan Lintasan B (B6 B8, B9, B10) memiliki nilai $\chi_{\mathrm{FD}}(\%)$ di atas $2,5 \%$, sehingga dapat dikatakan bahwa Lintasan A dan B aman dari bahaya longsor.

Untuk Lintasan $\mathrm{C}$ dan D dapat dikatakan bahwa hampir semua lintasan memiliki nilai $\chi_{\mathrm{FD}}(\%)$ diatas $2,5 \%$, kecuali $\mathrm{C} 2, \mathrm{C} 8, \mathrm{C} 9, \mathrm{D} 2$, dan D8. Hal ini sesuai dengan analisis sebelumnya bahwa Lintasan $\mathrm{C}$ dan $\mathrm{D}$ diduga telah mengalami erosi, sehingga dapat disimpulkan jika Lintasan $\mathrm{C}$ dan $\mathrm{D}$ merupakan daerah yang rawan akan terjadinya longsor.

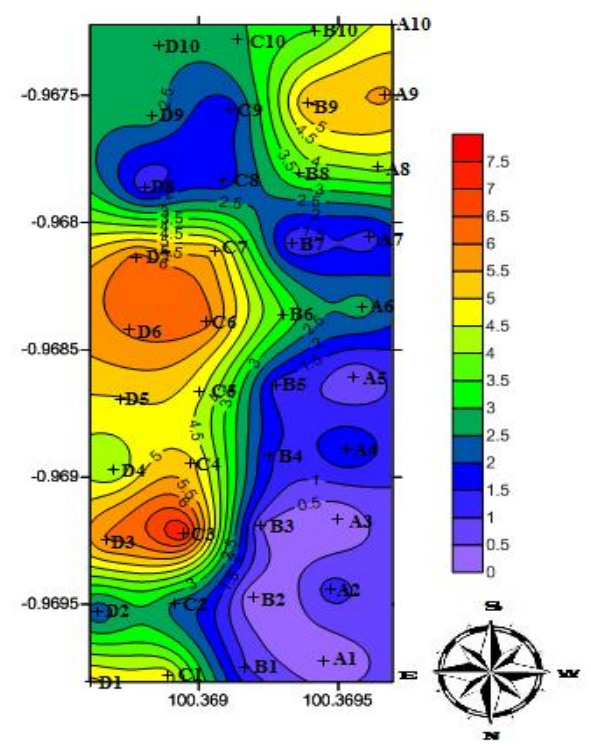

Gambar 5 Peta kontur sebaran $\chi_{\mathrm{FD}}(\%)$ pada empat lintasan pengambilan sampel 


\section{KESIMPULAN}

Menurut besarnya nilai suseptibilitas volum yang didapat, mineral pengontrol dari sampel merupakan mineral ferimagnetik. Menurut besarnya nilai suseptibilitas massa yang dihasilkan, sampel diduga mengandung mineral magnetik yaitu hematit $\left(\mathrm{Fe}_{2} \mathrm{O}_{3}\right)$. Dikarenakan sampel berasal dari lokasi yang sama, maka jenis kandungan mineral magnetik pada sampel diperkirakan sama, oleh karena itu perbedaan nilai suseptibilitas terjadi karena jumlah kandungan mineral magnet yang berbeda. Berdasarkan hubungan antara ketinggian dengan suseptibilitass magnetik, terdapat dua lintasan yang diduga telah mengalami erosi. Hal ini dikarenakan nilai suseptibilitas magnetik bertambah dengan berkurangnya ketinggian. Berdasarkan keberadaan bulir superparamagnetik, Lintasan C dan D memiliki butiran lebih halus dibandingkan sampel lokasi A dan B. Tanah yang memiliki butiran halus lebih mudah menyerap air karena memiliki luas permukaan yang lebih besar. Air yang terserap ke dalam tanah akan terakumulasi di atas bidang gelincir, sehingga dapat menyebabkan timbulnya gerak lateral pada tanah atau longsor. Berdasarkan hal tersebut Lintasan C dan D lebih besar kemungkinan terjadinya bencana longsor dibandingkan dengan Lintasan A dan B.

\section{DAFTAR PUSTAKA}

Dearing, J., Environmental Magnetic Suseptibility Using the Bartington MS2 System (Chi Publishing, England, 1999).

Dona, I.R., Akmam, Sudiar, N.Y., 2015, Identifikasi Bidang Gelincir Menggunakan Metode Geolistrik Tahanan Jenis Konfigurasi Schlumberger di Bukit Lantiak Kecamatan Padang Selatan, Pillar of Physics, Vol.5, hal. 1-8.

Jamil, M., Togubu, J., 2016, Implementasi Teknologi Wireless Sensor Network (WSN) untuk Monitoring Pergeseran Tanah, Jurnal PROtek, Vol.3, No.2, hal. 46-89.

Kosaka, K., "Evaluating Landslide Deposits Along the Tsurakawa Fault Zone Using Magnetic Suseptibilty", Bulletin Enginering Geol Environment, 58, 179-182 (2000).

Mullins, C., "Magnetic Susceptibility of The Soil and Its Significant in Soil Science a Review, Sil Science", British Society of Soil Science, 28, 223-246 (1977)

Nazarok, P., Kruglov, O., Menshov,. O., Kutsenko, M, dan Sukhorada, A., "Mapping Soil Erosion Using Magnetic Susceptibility. A Case study in Ukraine", Solid Earth Discuss, 6, 831-848 (2014).

Pratiwi, R. A., Prakoso, A. G., Darmasetiawan, R., Agustine, E., Kirana, K. H., Fitriani, D., "Identifikasi Sifat Magnetik Tanah di Daerah Tanah Longsor", Prosiding Seminar Nasional Fisika (E-journal) SNF2016, 5, 182-187 (2016).

Ramdhani, R., Fitriani, D., Kirana, K. H., Wijatmoko, B., Sutanto, O., 2016, "Magnetic Properties of Soils From Landslide Potential Area", $6^{\text {th }}$ Asian Physics Symposium, Bandung.

Solomon, J. S., Ahmed, A. L., Adamu, I. H., Dimu, O. O., "Identifying Anthropogenic Metallic Pollutants Using Frequency Dependent Magnetic Susceptibility Measurements In Abuja Metropolis", Currents Trends In Natural Sciences, 6, 13-22 (2017).

Tarling, D.H. dan Hrouda, F., The Magnetic Anisotropy of Rocks (Chapman \& Hall, London, 1993).

Taslimah., 1999, Analisis Batuan Andesit Dengan Metode Difraksi Sinar-X, Jurnal Kimia Sains dan Aplikasi, Vol. 2, hal 34-38.

Thompson, R., Oldfield, F., Enviromental Magnetism (George Allen and Unwin, London, 1986).

Zakaria, Z., 2009, Analisis Kestabilan Lereng, Geologi Teknik FTG-UNPAD, Bandung.

Bappeda, 2009, Kondisi Umum Kota Padang, http ://www.bappeda.padang.go.id diakses Mei 2018.

BNPB, 2016, Data Bencana, http://www.bnpb.go.id/data-bencana/lihat-data, diakses Januari 2018.

BPBD, 2013, Peta Kapasitas Bencana Tanah Longsor di Kota Padang Sumatera Barat, Padang. 